\title{
Mengukur Tingkat Kematangan Tata Kelola Sistem Informasi Akademik Menggunakan COBIT 4.1 dan Balanced Scorecard
}

\author{
Measuring the Maturity Level of Academic Information System \\ Governance Using COBIT 4.1 and the Balanced Scorecard
}

\author{
Elvis Pawan*1, Ema Utami², Asro Nasiri ${ }^{3}$ \\ ${ }^{1}$ STIMIK Sepuluh Nopember, ${ }^{2,3}$ Program Pasca Sarjana Universitas Amikom Yogyakarta \\ E-mail: *1 elvispawan09@gmail.com, ${ }^{2}$ emma@nrar.net, ${ }^{3}$ asro@amikom.ac.id
}

\begin{abstract}
Abstrak
Dalam perkembangan lembaga pendidikan sangat ditentukan oleh teknologi informasi (TI). Pada STIMIK Sepuluh Nopember Jayapura terdapat masalah dalam hal belum menyadari pentingnya untuk meningkatkan efisiensi biaya. Sehingga perlu dilakukan pengukuran untuk mengetahui tingkat kematangan lembaga dalam hal pengelolaan efisiensi biaya. Tata kelola TI sangat dibutuhkan untuk mengetahui sejauh mana pemanfaatan TI demi tercapaianya visi dan misi lembaga. Salah satu proses penting dalam penerapan tata kelola TI adalah melakukan evaluasi untuk mengetahui sejauh mana institusi menerapkan tata kelola yang baik. Penelitian ini menjelaskan bagaimana lembaga pendidikan dapat meningkatkan efisiensi biaya dan kontribusinya terhadap profitabilitas bisnis. Balanced Scorecard merupakan sebuah kerangka kerja yang baik untuk melakukan penilaian terhadap kinerja Organisasi. Dalam hal ini COBIT dan Balanced scorecard memberikan sebuah patokan pada financial perspektif yang dapat dijadikan acuan manajemen sebuah institusi yang ingin melakukan pembenahan khususnya dalam efisiensi biaya. Penelitian ini menghasilkan cara meningkatkan maturity level yang dapat dijadikan acuan oleh lembaga dalam menyusun tata kelola TI yang sesuai dengan best practice COBIT 4.1. Pada penelitian ini diperoleh kesimpulan bahwa tingkat kematangan tata kelola lembaga saat ini khususnya PO5 = 2,37 dan DS6=2,69, berada pada level 2.
\end{abstract}

Kata Kunci - Tata Kelola TI, COBIT, Balanced Scorecard

\begin{abstract}
In the development of educational institutions is largely determined information technology (IT). STIMIK Sepuluh November Jayapura there were problems in terms of not realizing the importance of increasing cost efficiency. Necessary to measure the maturity level of the institution in terms of managing cost efficiency. IT governance of an institution is needed to find out how far IT is used for achieving vision and mission. The most important processes in implementing IT governance is conducting an evaluation that aims to determine the extent of institutions in implementing good governance. This study explains how an educational institution can improve cost efficiency and its contribution to business profitability. The Balanced Scorecard is a good framework for assessing Organizational performance. COBIT and the Balanced Scorecard provide a benchmark for financial perspective that can be used as a reference for management in an institution that wants to make improvements, especially cost efficiency. This study has a way to improve the maturity level that can be used as a reference by the institution in compiling IT governance that is in accordance with COBIT best practices. In this study concluded that the current maturity level of institutional governance, especially PO5=2.37 and DS6=2.69, is at level 2
\end{abstract}

Keywords - 3-5 IT Governance, COBIT, Balanced Scorecard 


\section{PENDAHULUAN}

Penerapan teknologi informasi akan bermanfaat jika penerapan sesuai dengan tujuan visi dan misi organisasi atau institusi dengan menerapkan strategi bisnis dan strategi sistim teknologi informasi. [1] Diperlukan analisa yang cukup berbagai faktor yang mempengaruhi terbentuknya suatu perencanaan strategi sistem atau teknologi informasi yang adaptable dan selaras atau satu tujuan dengan strategi bisnis [1].

STIMIK Sepuluh Nopember Jayapura merupakan sebuah Lembaga Pendidikan yang berkedudukan di kota Jayapura dimana dikeluarkan izin operasional melalui keputusan menteri Pendidikan nasional Republik Indonesia dengan nomor: 31/D/O/2006. Sesuai dengan visi dan misi institusi yang tertuang didalam rencana strategis STIMIK Sepuluh Nopember Jayapura bahwa "Menjadi Perguruan Tinggi swasta yang berdaya saing dan unggul di Provinsi Papua pada tahun 2025 dalam bidang ilmu Komputer" [2]. Akan tetapi setelah terbentuknya lembaga tersebut manajemen belum mengetahui sejauh mana progress untuk mencapai sasaran yang dimaksud, itu bukan tanpa alasan karena sampai saat ini belum pernah dilakukan sebuah evaluasi dalam bentuk pengukuran tata kelola pada sistem yang digunakan. Penelitian ini difokuskan pada proses COBIT dengan pemetaan yang telah ditentukan sesuai perspektif Balanced Scorecard:

1. Financial perspective Balanced Scorecard dengan tujuan bisnis Provide a good return on investment of IT-enabled business investments dan tujuan teknologi informasi Improve costefficiency and its contribution to business profitability, dengan proses COBIT PO5 dan DS6.

2. Merepresentasikan tingkat kematangan kedalam nilai mauturity level.

3. Penelitian ini dilakukan pada BAAK STIMIK Sepuluh Nopember Jayapura

Audit Teknologi Informasi pada hakekatnya merupakan salah satu dari bentuk audit, operasioanal, tetapi kini audit teknologi informasi sudah dikenal sebagai satu satuan jenis audit tersendiri yang tujuan utamanya lebih untuk meningkatkan tata kelola IT, sebagai suatu audit operasional terhadap manajemen sumber daya informasi yaitu efektivitas, efisiensi dan ekonomis tidaknya unit fungsional sistem informasi pada suatu organisasi [3].

Audit tersebut dapat dilakukan dengan beberapa framework yang ada diantaranya, COBIT, IT-IL, ISO 17799.[3]. Pada penelitian ini penulis menggunakan framework Control Objectives For Information Technology (COBIT) sebagai panduan dalam mengevaluasi TI. Pemilihan framework karena COBIT memiliki cakupan yang luas dibandingkan dengan yang lainnya. Framework COBIT lebih detail dan terperinci terdiri dari 318 activity, 34 level proses yang ada dan dibagi ke dalam empat domain.

1. Plan and Organise yang terdiri dari sepuluh proses terkait perencanaan dan penyelarasan strategi teknologi informasi dan strategi perusahaan atau organisasi

2. Acquire and Implement yang terdiri dari tujuh proses terkait pemilihan pengadaan dan penerapan teknologi informasi yang digunakan

3. Delivery and Support yang terdiri dari tiga belas proses terkait pelayanan teknologi informasi dan dukungan teknisnya

4. Monitoring dan Evaluate yang terdiri dari empat proses terkait pengawasan dan pengelolaan teknologi informasi pada perusahaan atau organisasi [3][4].

Faktor lain pemilihan kerangka kerja dengan framework COBIT karena mempunyai beberapa keunggulan pertama, Memiliki konsep yang searah dengan pengelolaan perusahaan. Kedua mempunyai definisi yang cukup, rinci dan terarah untuk pengelolaan sebuah perusahaan, ketiga mempunyai konsep keterkaitan kausal yang erat, sehingga lebih mudah untuk mengarahkan perusahaan, dari sasaran teknis ke strategis dan sebaliknya serta mampu menelusuri masalah dari lingkup yang besar ke lingkup yang lebih detil [5].

Balanced Scorecard dikembangkan oleh Kaplan dan Norton dapat diimplementasikan ke fungsi IT dan proses-prosesnya sehingga timbul konsep Information Technology Balanced Scorecard[6]. Balanced Scorecard adalah kumpulan ukuran kinerja yang terintegrasi yang diturunkan dari misi dan visi perusahaan untuk mendukung strategi perusahaan secara 
keseluruhan[7]. Balanced Scorecard mempunyai identifikasi struktur ataupun kerangka yang ada Lembaga untuk mencapai dan merealisasikan visi dan misi lembaga, dan hal ini dijelaskan kedalam empat perspektif Balanced Scorecard[7].

Tata kelola (Governance) merupakan turunan dari kata "government” yang artinya membuat kebijakan (Policies) yang sejalan dan selaras dengan keinginan/aspirasi masyarakat atau kontituan [8]. Agar layanan TI berjalan sesuai dengan yang diharapkan, perlu ditunjang dengan tata kelola TI. [9] Pada penerapannnya agar tata kelola TI berlangsung dengan efektif, organisasi perlu menilai sejauh mana tata kelola yang sekarang berlangsung dan mengidentifikasi peningkatan yang dapat dilakukan, hal tersebut berlaku pada semua proses yang perlu dikelola yang terkandung dalam TI dan proses tata kelola itu sendiri. [9]

Informasi system audit and control association (ISACA) memperkenalkan sebuah kerangka untuk mengelola IT Governance di sebuah perusahaan yang dikenal dengan nama COBIT. [10] COBIT menyediakan seperangkat praktek yang dapat diterima pada umumnya karena dapat membantu meningkatkan nilai teknologi informasi dan menurunkan resiko. COBIT merupakan sekumpulan dokumentasi best practice untuk tata kelola TI dapat membantu seorang auditor, manajemen dan pengguna untuk menghubungkan kesenjangan atau (gap) antara resiko bisnis, kebutuhan control dan permasalahan teknis. [11]

COBIT 4.1 memiliki model kematangan (Maturity Model) yang digunakan mengontrol semua proses TI dengan menggunakan cara penilaian (scoring) sehingga suatu organisasi dapat menilai proses-proses TI yang dimilikinya dimulai dari skala 0 sampai 5. Berikut pada Tabel 1 adalah penjelasan tingkatan Matury Model. [3] [10].

Tabel 1. Maturity Model

\begin{tabular}{|c|c|}
\hline Level & Kriteria Kematangan \\
\hline 0 Non Existent & $\begin{array}{l}\text { Lembaga/instansi tidak mengetahui bahwa terdapat Kekurangan dan } \\
\text { permasalaahn yang menyeluruh terhadap proses apapun yang dapat harus diatasi }\end{array}$ \\
\hline 1 Initial /Ad Hoc & $\begin{array}{l}\text { Terdapat bukti bahwa Instansi/lembaga mengetahui adanya permasalahan yang } \\
\text { harus diatasi. Belum terdapat proses standar, namun menggunakan pendekatan } \\
\text { awal yang cenderung diperlakukan secara individu atau per kasus. Secara umum } \\
\text { pendekatan kepada pengelolaan proses tidak terorganisasi }\end{array}$ \\
\hline $\begin{array}{l}2 \text { Repeatable but } \\
\text { Intuitive }\end{array}$ & $\begin{array}{l}\text { Dibuatkan prosedur untuk pekerjaan yang sama untuk dipakai oleh berbagai } \\
\text { pihak. Belum ditemukan pelatihan formal atau sosialisasi aturan standar dan } \\
\text { tanggung jawab diserahkan kepada masing-masing PIC. Terdapat tingkat } \\
\text { kepercayaan yang tinggi terhadap pengetahuan ndividu/perorangan sehingga } \\
\text { kemungkinan untuk terjadi error sangat besar }\end{array}$ \\
\hline 3 Defined & $\begin{array}{l}\text { Prosedur distandarisasi dan didokumentasikan kemudian dikomunikasikan } \\
\text { melalui pelatihan. Kemudian diamanatkan bahwa proses-proses tersebut harus } \\
\text { diikuti. Namun kesahan sulit terdeteksi. Aturan sendiri tidak lengkap namun } \\
\text { sudah memformalkan praktek yang sedang dijalankan }\end{array}$ \\
\hline $\begin{array}{l}4 \text { Managed } \\
\text { and Measurable }\end{array}$ & $\begin{array}{l}\text { Lembaga memantau dan mengawasi serta mengukur kepatutan terhadap aturan } \\
\text { atau prosedur dan mengambil tindakan jika proses tidak dapat dikerjakan secara } \\
\text { efektif. Proses berada dibawah peningkatan yang tetap dan penyediaan praktek } \\
\text { yang baik. Otomatisasi dan perangkat digunakan dalam batasan tertentu }\end{array}$ \\
\hline 5 Optimeze & $\begin{array}{l}\text { Proses telah dipilih ke dalam tingkat praktek yang baik, berdasarkan hasil dari } \\
\text { perbaikan berkelanjutan dan permodelan kedewasaan dengan perusahaan lain }\end{array}$ \\
\hline
\end{tabular}


Teknik pengukuran maturity level menggunakan beberapa statement (pernyataan) dimana setiap pernyataan dapat dinilai tingkat kepatutannya dengan menggunakan standar nilai, seperti pada Tabel 2.

Tabel 2. Standar Penilaian maturity level (Pederiva, 2007)

\begin{tabular}{|l|c|}
\hline \multicolumn{2}{|c|}{ Complience Level Numeric Values } \\
\hline Agreement With Statement & Complience Value \\
\hline Tidak Setuju & 0 \\
\hline Kurang Setuju & 0,33 \\
\hline Setuju & 0,66 \\
\hline Sangat Setuju & 1 \\
\hline
\end{tabular}

Balanced Scorecard dikembangkan oleh Kaplan dan Norton dapat diimplementasikan ke fungsi IT dan proses-prosesnya sehingga timbul konsep Information Technology Balanced Scorecard[6]. Pengertian Balanced scorecard merupakan perencanaan strategis dan sistem manajemen yang digunakan secara luas baik dalam organisasi, meningkatkan komunikasi internal dan eksternal dan mengawasi kinerja organisasi sesuai dengan tujuan strategi perusahaan. Balanced Scorecard juga merupakan Alat bantu dalam melakukan penilaian kinerja dan konsepnya berupa keseimbangan antara perspektif keuangan dan perspektif non keuangan, sebagai bagian dari strategi organisasi dimasa mendatang [12].

Balanced scorecard tebagi kedalam empat perspektif yaitu: [7]

1. Perspektif Finansial, Tujuan finansial mungkin sangat berbeda untuk setiap tahap siklus hidup bisnis. Teori strategi bisnis menawarkan beberapa strategi yang berbeda yang dapat diikuti oleh unit bisnis, dari pertumbuhan pangsa pasar yang agresif sampai kepada konsolidasian bisnis, keluar, dan likuidasi

2. Perspektif Pelanggan, menyatakan kumpulan ukuran pelanggan utama pada umumnya untuk semua jenis perusahaan atau lembaga. Kelompok pengukuran ini diantaranya ukuran Pangsa pasar, retensi terhadap pelanggan, akuisisi terhadap pelanggan, kepuasan terhadap pelanggan dan profitabilitas pelanggan

3. Perspektif Bisnis Internal, dijelaskan bahwa pada perspektif bisnis internal para manajer melakukan identifikasi berbagai proses yang sangat penting untuk mencapai tujuan pelanggan dan pemegang saham. Untuk Balanced Scorecard para manajer disarankan untuk menentukan rantai nilai internal lengkap yang diawali dengan proses inovasi, dilanjutkan dengan proses operasi dan diakhiri dengan layanan purna jual.

4. Perspektif Pembelajaran dan Pertumbuhan, Tujuan didalam perspektif pembelajaran dan pertumbuhan adalah menyediakan infrastruktur yang memungkinkan tujuan ambisius tiga perspektif lainnya yang dapat dicapai. Tujuan dalam perspektif pembelajaran dan pertumbuhan merupakan factor pendorong dihasilkannya kinerja yang istimewa dalam tiga perspektif scorecard

Penggunaan Balanced Scorecard (BSC) telah menyebar luas sebagai pengukuran kinerja dan sistem manajemen. Premis dasar bahwa evaluasi dari suatu instansi seharusnya tidak terbatas pada evaluasi keuangan tradisional tetapi harus dilengkapi dengan langkah-langkah mengenai kepuasan pelanggan, proses internal, serta pembelajaran dan pertumbuhan[6].

Dalam perkembangan selanjutnya, Balanced Scorecard tidak hanya dipakai untuk mengukur kinerja organisasi saja, namun berkembang menjadi inti sistem manajemen strategi. Lebih dari sekadar pengukuran, Balanced Scorecard merupakan sistem manajemen yang memotivasi breakthrough improvement dalam semua bidang kritis, seperti produk, proses, customer, dan pengembangan pasar. Ada empat proses managing strategy yang mengkombinasikan tujuan jangka panjang dan jangka pendek secara optimal yaitu proses menterjemahkan visi (translating the vision), communication and linking, proses business planning, dan proses feedback and learning [13]. 
Kelebihan Balanced Scorecard adalah diantaranya dapat mengembangkan analisis kinerja TI secara luas dan spesifik, meningkatkan efektivitas proyek teknologi informasi, meningkatkatkan hubungan dan dialog teknologi informasi, posisi teknologi informasi dapat meningkatkan keunggulan bersaing[14].

\section{METODE PENELITIAN}

Penelitian ini menggunakan metode survey research, merupakan metode penelitian bersifat kualitatif. Penelitian Kualitatif merupakan jenis penelitian yang menghasilkan temuantemuan yang tidak diperoleh oleh alat-alat prosedur statistik atau alat-alat kuantifikasi lainnya[15].

\subsection{Metode Pengumpulan data}

Pada penelitian ini, metode pengumpulan data terbagi menjadi 4 (empat) bagian yaitu studi Pustaka, kuesioner, wawancara, observasi.

Observasi merupakan metode pengumpulan data dan informasi dengan mencari data kepustakaan berupa buku, jurnal ilmiah, e-book, dan lain sebagainya yang ada kaitannya dengan penelitian [16].

Kuesioner merupakan pengumpulan data dengan menganalisis hasil kuesioner dengan pihak yang mampu memberikan informasi terhadap permasalahan yang sedang diteliti [16]. Dalam pemilihan responden menggunakan RACI Chart COBIT 4.1 dengan kriteria pada Responsible, Accountable, Consulted, Informed (RACI). Menjelaskan bahwa RACI chart mempunyai fungsi untuk mejelaskan peran dan tanggung jawab suatu fungsi dalam lembaga terhadap suatu aktivitas tertentu didalam IT control objective [17].

Wawancara dalam tahapan ini, peneliti melakukan pengumpulan data dengan cara berdiskusi atau tanya jawab kepada pihak-pihak yang terkait diantaranya Ketua STIMIK Sepuluh Nopember Jayapura, Pembantu Ketua I Bidang Akademik, Pembantu Ketua II Bidang Sumber daya Manusia dan Keuangan, Pembantu Ketua III bidang Kemahasiswaan, Kepala Laboratorium dan Staf, Kepala Unit Penjaminan Mutu, Kepala BAAK, Kepala LPPM. Hasil wawancara akan menjadi pertimbangan dalam pengolahan kuesioner serta penentuan nilai kematangan yang ada pada tiap-tiap domain atau proses yang diteliti.

Obeservasi metode ini merupakan cara mengumpulkan data dengan melakukan pengamatan langsung Pada STIMIK Sepuluh Nopember Jayapura terkait sistem atau kondisi yang sedang diterapkan.

\subsection{Alur Penelitian}

Pada penelitian yang dilakukan terdapat beberapa langkah pokok yang di representasikan dalam gambar alur penelitian pada Gambar 1.

a. Studi Literatur

Tahap studi literatur adalah langkah penelitian yang dilakukan dengan mempelajari data dan informasi yang bersumber dari buku, jurnal dan hasil penelitian terdahulu yang sesuai dengan topik yang dibahas pada penelitian ini.

b. Pengumpulan data dan Informasi

Pada tahapan pengumpulan data dan informasi adalah dengan melakukan studi pustaka, observasi, wawancara, dan kuesioner. Pada tahap wawancara dilakukan dengan mewawancarai pemangku kepentingan kepala BAAK, kepala Laboratorium, Ketua dan Pembantu Ketua STIMIK Sepuluh Nopember Jayapura. Pada tahap kuesioner dilakukan dengan menyebarkan kuesioner pada responden yang telah ditentukan dengan menjawab pernyataan-pernyataan yang sesuai dengan COBIT 
c. Analisis tingkat kematangan kondisi saat ini (as-is)

Pada tahap ini peneliti melakukan analisis yang ada pada STIMIK Sepuluh Nopember Jayapura yang tujuannya adalah mendapatkan nilai maturity level pada sistem yang sedang berjalan

d. Analisis tingkat kematangan yang diharapkan (to-be)

Pada tahap ini peneliti melakukan analisis terhadap tingkat kematangan yang diharapkan STIMIK Sepuluh Nopember Jayapura yang tujuannya adalah mendapatkan nilai maturity level pada sistem yang akan dituju.

e. Menentukan Nilai kesenjangan (gap)

Pada tahap ini peneliti menentukan nilai kesenjangan antara tingkat kematangan diharapkan dengan tingkat kematangan yang sedang dijalankan

f. Pemberian rekomendasi Perbaikan

Pada tahap ini peneliti memberikan rekomendasi perbaikan terkait hal-hal yang dapat dilakukan oleh STIMIK Sepuluh Nopember Jayapura dalam mengefisienkan biaya.

g. Penarikan Kesimpulan

Pada tahap ini peneliti menarik kesimpulan dari hasil penelitian serta memberikan saran baik kepada colon peneliti ataupun bagi pembaca yang.

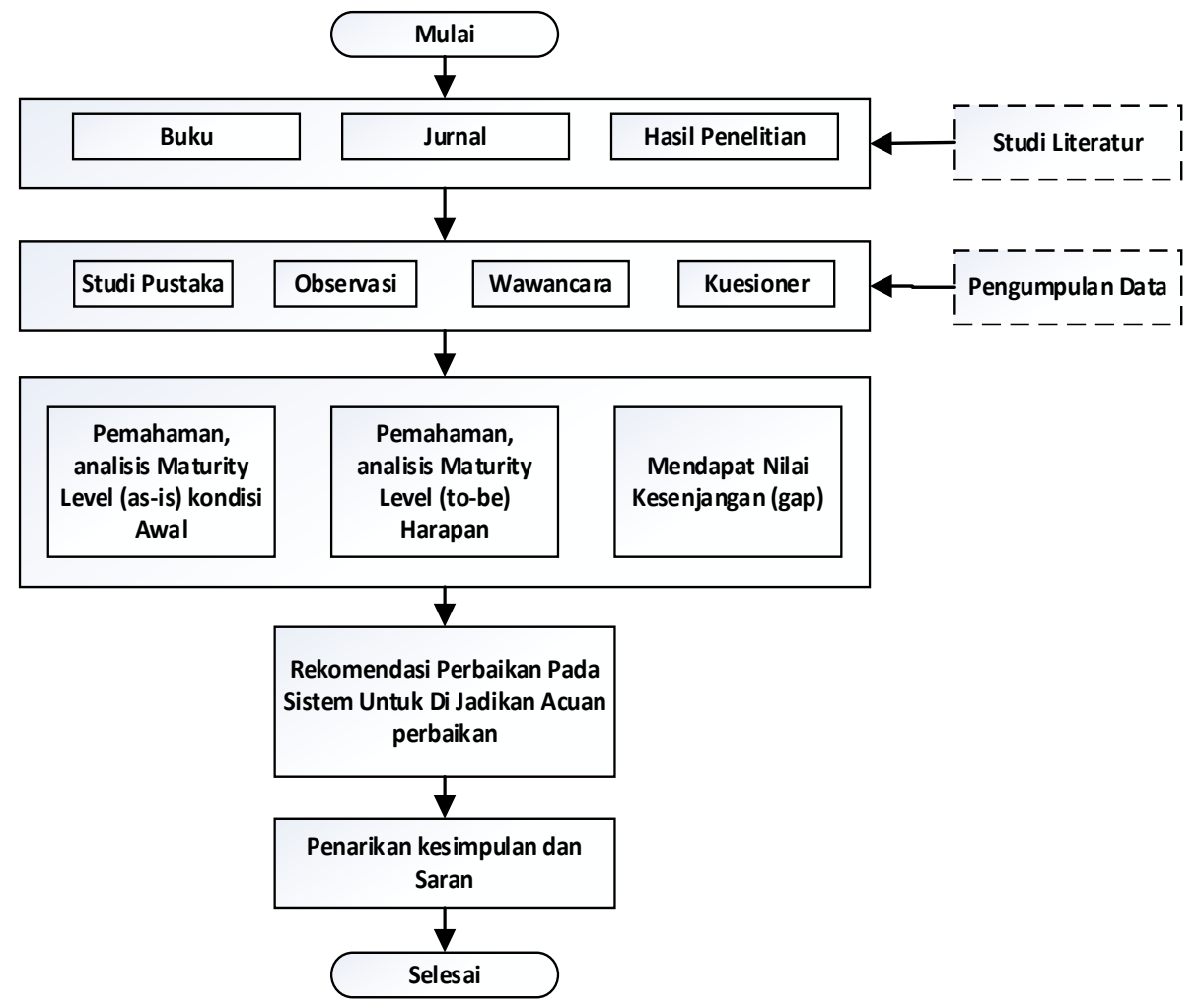

Gambar 1. Alur Penelitian

\section{HASIL DAN PEMBAHASAN}

Pada penentuan tujuan bisnis dan tujuan teknologi informasi yang diteliti pada STIMIK Sepuluh Nopember Jayapura penulis menyesuaikan dengan kebutuhan Lembaga tersebut. Sebuah Lembaga yang sedang dalam perkembangan dituntut untuk meningkatkan efisiensi biaya dan memaksimalkan pemasukan demi terselenggaranya operasional yang baik. 
Citec Journal, Vol. 5, No. 2, Februari 2018 - April 2018

ISSN: 2460-4259

\subsection{Waktu dan Tempat Penelitian}

Penelitian ini dilakukan mulai dari 30 Juli - 15 Oktober 2018 yang bertempat di STIMIK Sepuluh Nopember Jayapura.

\subsection{Analisis dan Pengolahan Data}

Pada Tahapan ini peneliti memilih atau menentukan perspektif Balanced Scorecard serta proses COBIT yang disesuaikan dengan kebutuhan Lembaga saat ini. Adapun Balanced Scorecard dan proses COBIT yang dipilih dapat dilihat pada tabel 3. Hubungan antara BSC dan COBIT

Tabel 3. Hubungan BSC dan COBIT

\begin{tabular}{|c|l|l|l|}
\hline $\begin{array}{c}\text { Perspektif Balanced } \\
\text { Scorecard }\end{array}$ & \multicolumn{1}{|c|}{ Business Goals } & \multicolumn{1}{|c|}{ IT Goals } & Proses COBIT \\
\hline Financial perspective & $\begin{array}{l}\text { Provide a good return on } \\
\text { investment of IT-enabled } \\
\text { business investments }\end{array}$ & $\begin{array}{l}\text { informasi Improve IT's cost- } \\
\text { efficiency and its contribution } \\
\text { to business profitability }\end{array}$ & PO5 DS6 \\
\hline
\end{tabular}

\subsection{Hasil Pengukuran Maturity Level}

Berdasarkan kuesioner menggunakan COBIT 4.1 diperoleh hasil seperti yang terdapat pada tabel 4. Hasil pengukuran proses COBIT

Tabel 4. Hasil Pengukuran proses COBIT

\begin{tabular}{|l|l|c|}
\hline No & \multicolumn{1}{|c|}{ Proses } & Nilai Kematangan \\
\hline 1 & PO5 $\rightarrow$ Mengatur Investasi TI & 2.37 \\
\hline 2 & DS6 $\rightarrow$ Identifikasi dan Biaya tambahan & 2.69 \\
\hline
\end{tabular}

Pada masing-masing proses didalam domain yang telah dipilih, Plan and Organize diwakili oleh PO5 dan DS6 berdasarkan Balanced Scorecard. Proses PO5 memiliki nilai kematangan sebesar 2.37 yakni pada level Repeatable but Intuitive demikian DS6 memiliki nilai kematangan sebesar 2.69 dengan kategori Repeatable but Intuitive pada level ini dibuatkan prosedur untuk pekerjaan yang sama untuk dipakai oleh berbagai pihak. Belum terdapat terdapat Belum terdapat proses standar, namun menggunakan pendekatan awal yang cenderung diperlakukan secara individu atau per kasus. Tingkat kepercayaan yang tinggi terhadap kemampuan individu/perorangan sehingga sangat mungkin terjadi kesalahan sangat besar.

Dalam penelitian dibedakan istilah antara tingkat kematangan dan nilai kematangan dimana nilai kematangan merupakan bilangan pecahan yang merepresentasikan proses pencapaian menuju suatu tingkat kematangan tertentu sesuai dengan teori COBIT. Sedangkan tingkat kematangan menunjukkan tingkat kematangan yang dicapai Lembaga dalam menjalankan sistem dan bentuknya berupa bilangan bulat.

\subsection{Tingkat Kematangan yang diharapkan (to-be)}

To-be diperoleh dari hasil wawanca dengan pemangku kepentingan pada STIMIK Sepuluh Nopember Jayapura diantanya Ketua STIMIK Sepuluh Nopember Jayapura, Pembantu Ketua I, Pembantu Ketua II, Pembantu Ketua III, Kepala BAAK dan Kepala Laboratorium. Para pemangku kepentingan ini memahami bahwa dalam hal melakukan efisiensi biaya adalah hal yang sangat utama demi terselenggaranya operasional lembaga. Analisis yang diperoleh dari hasil kuesioner yang disebarkan dengamn mempertimbangankan keadaan STIMIK Sepuluh Nopember Jayapura, maka tingkat kematangan yang diharapkan adalah level 4 (Managed and Measurable). Pada kondisi ini lembaga mengawasi dan mengukur kepatutan terhadap prosedur dan mengambil tindakan jika proses tidak dapat dikerjakan secara efektif, proses berada di bawah peningkatan 
yang tetap, dan penyediaan praktek yang baik. Otomatisasi dan perangkat digunakan dalam batasan tertentu. Hal ini dijelaskan pada Tabel 5.

Tabel 5. Tingkat kematangan saat ini dan tingkat kematangan diharapkan

\begin{tabular}{|c|c|c|c|c|}
\hline No & Proses & $\begin{array}{c}\text { Nilai } \\
\text { Kema- } \\
\text { tangan }\end{array}$ & $\begin{array}{l}\text { Tingkat Kematangan Saat Ini } \\
\text { (as-is) }\end{array}$ & $\begin{array}{c}\text { Tingkat Kematangan } \\
\text { Diharapkan (to-be) }\end{array}$ \\
\hline 1 & $\begin{array}{l}\text { PO5 } \rightarrow \\
\text { Mengatur } \\
\text { Investasi } \\
\text { TI }\end{array}$ & 2,37 & $\begin{array}{l}2 \text { Repeatable but Intuitive } \\
\text { Dibuatkan prosedur untuk pekerjaan } \\
\text { yang sama untuk dipakai oleh berbagai } \\
\text { pihak. Belum ditemukan pelatihan } \\
\text { formal atau sosialisasi aturan standar } \\
\text { dan tanggung jawab diserahkan kepada } \\
\text { masing -masing PIC. Terdapat tingkat } \\
\text { kepercayaan yang tinggi terhadap } \\
\text { pengetahuan individu/perorangan } \\
\text { sehingga kemungkinan terjadi kesalahan } \\
\text { sangat besar }\end{array}$ & $\begin{array}{l}\text { Managed and Measurable } \\
\text { Manajemen mengawasi dan } \\
\text { mengukur kepatutan terhadap } \\
\text { prosedur dan mengambil tindakan } \\
\text { jika proses tidak dapat dikerjakan } \\
\text { secara efektif. Proses peningkatan } \\
\text { yang konstan dan dapat } \\
\text { memberikan praktek yang baik. } \\
\text { Otomatisasi dan perangkat yang } \\
\text { digunakan dalam batasan tertentu }\end{array}$ \\
\hline 2 & $\begin{array}{l}\text { DS6 } \rightarrow \\
\text { Identifikas } \\
\text { i dan } \\
\text { Biaya } \\
\text { tambahan }\end{array}$ & 2,69 & $\begin{array}{l}2 \text { Repeatable but Intuitive } \\
\text { Dibuatkan prosedur untuk pekerjaan } \\
\text { yang sama untuk dipakai oleh berbagai } \\
\text { pihak. Belum ditemukan pelatihan } \\
\text { formal atau sosialisasi aturan standar } \\
\text { dan tanggung jawab diserahkan kepada } \\
\text { masing -masing PIC. Terdapat tingkat } \\
\text { kepercayaan yang tinggi terhadap } \\
\text { pengetahuan individu/perorangan } \\
\text { sehingga kemungkinan terjadi error } \\
\text { sangat besar }\end{array}$ & $\begin{array}{l}\text { Managed and Measurable } \\
\text { Manajemen mengawasi dan } \\
\text { mengukur kepatutan terhadap } \\
\text { prosedur dan mengambil tindakan } \\
\text { jika proses tidak dapat dikerjakan } \\
\text { secara efektif. Proses peningkatan } \\
\text { yang konstan dan dapat } \\
\text { memberikan praktek yang baik. } \\
\text { Otomatisasi dan perangkat yang } \\
\text { digunakan dalam batasan tertentu }\end{array}$ \\
\hline
\end{tabular}

Untuk mendapatkan gambaran yang lebih jelas terhadap tingkat kematangan saat ini dan tingkat kematangan yang diharapkan maka peneliti menggambarkan dalam bentuk diagram rising star seperti pada Gambar 2.

\begin{tabular}{|c|c|c|c|c|c|c|c|}
\hline & \multicolumn{6}{|c|}{ Tingkat Kematangan } \\
\hline & & 1 & 2 & 3 & & 4 & 5 \\
\hline \multirow{2}{*}{ Proses } & PO5 & & $\bullet$ & & $\longrightarrow$ & & \\
\hline & DS6 & & - - & & $\longrightarrow$ & & \\
\hline
\end{tabular}

Gambar 2. Diagram rising star (representasi nilai as-is dan to-be)

\subsection{Selisi Nilai Kematangan saat ini dan kematanga diharapkan (Gap)।}

Dari hasil analisis nilai kematangan saat ini dan kematangan diharapkan dapat ditentukan nilai kesenjagan yang akan digunakan sebagai acuan dalam pemberian rekomendasi perbaikan pada STIMIK Sepuluh Nopember Jayapura. adapun nilai kesenjangan dapat dilihat pada tabel 6 . Nilai kesenjangan (gap)

Tabel 6. Nilai Kesenjangan (gap)

\begin{tabular}{|l|l|l|l|l|l|}
\hline No & Proses & $\begin{array}{l}\text { Nilai } \\
\text { Kematangan } \\
\text { saat ini (as-is) }\end{array}$ & $\begin{array}{l}\text { Pembulatan } \\
\text { (tingkat } \\
\text { Kematangan) }\end{array}$ & $\begin{array}{l}\text { Tingkat } \\
\text { Kematangan } \\
\text { diharapkan }\end{array}$ & $\begin{array}{l}\text { Selisih } \\
\text { (Gap) }\end{array}$ \\
\hline 1 & PO5 $\rightarrow$ Mengatur Investasi TI & 2.37 & 2 & 4 & 2 \\
\hline 2 & $\begin{array}{l}\text { DS6 } \rightarrow \text { Identifikasi dan Biaya } \\
\text { Tambahan }\end{array}$ & 2.69 & 2 & 4 & 2 \\
\hline
\end{tabular}




\subsection{Rekomendasi}

Memberikan usulan yang akan dijadikan acuan dalam perbaikan dalam mencapai tujuan yang sesuai dengan visi dan misi Lembaga. Pemberian rekomendasi dilakukan berdasarkan hasil analisis yang telah dilakukan pada tahap sebelumnya. Rekomendasi yang diberikan berupa tindakan yang perlu dilakukan pada masing-masing proses khususnya yang menjadi objek penelitian ini.

Perlu diketahui bahwa rancangan solusi adalah bahwa proses menuju penyempurnaan adalah hal yang alamiah, secara terus menerus diupayakan sampai mencapai tujuan yang ditargetkan dalam kurun waktu tertentu, dan itu dilakukan secara bertahap.

Pada hasil penelitian ini menyatakan bahwa posisi STIMIK Sepuluh Nopember Jayapura saat ini sedang berada pada level 2 (Repeatable but Intuitive) dimana hal tersebut jika disesuaikan dengan model kematangan pada COBIT 4.1 maka pada level ini proses yang bejalan dibuatkan prosedur untuk pekerjaan yang sama untuk dipakai oleh berbagai pihak. Belum ditemukan pelatihan formal atau sosialisasi aturan standar dan tanggung jawab diserahkan kepada masing masing PIC. Kepercayaan yang tinggi terhadap pengetahuan individu/perorangan sehingga kemungkinan terjadi kesalahan sangat besar. Untuk dapat mencapai Peneliti memberikan rekomendasi kepada pihak-pihak pemangku kepentingan yang secara langsung berada pada sistem dimaksud, adapun rekomendasi yang diberikan adalah sebagai berikut.

a. Rekomendasi proses PO5

1. Perlu dilakukan pengukuran secara berkala dan konsisten terhadap Penggunaan sistem, kinerja, kapasitas

2. Sebaiknya Informasi selalu diperbaharui, dilakukan standarisasi terhadap kinerja, memprediksi kejadian yang akan merugikan.

3. Lembaga menyediakan Alat pemantau otomatis disediakan untuk memantau ruang sumber tertentu daya seperti, Ruang server, gateway jaringan, disk dan lain-lain.

4. Lembaga memberikan kepuasan kepada pengguna layanan yang selalu mengharapkan layanan diperbaharui secara cepat.

5. Lembaga menyediakan metrik untuk mengukur kapasitas TI walaupun penerapannya belum secara konsisten.

b. Rekomendasi proses DS6

1. Lembaga bertanggung jawab terhadap biaya layanan informasi serta dijelaskan dan dipahami kepada berbagai pihak dan Lembaga menyediakan pelatihan formal

2. Biaya langsung maupun biaya tidak langsung dilaporkan dengan tepat waktu secara otomatis kepada pemangku kepentingan.

3. Lembaga melakukan pemantauan dan evaluasi, mengambil tindakan jika terdeteksi biaya deviasi.

4. Pelaporan biaya layanan informasi selalu dipantau oleh pemangku kepentingan.

5. Lembaga selalu meninjau agar alokasi anggaran atau biaya tetap pada batas wajar.

6. Lembaga menyediakan sistim akuntansi otomatis yang difokuskan pada layanan informasi bukan pada proses bisnis.

7. Tujuan dan metrik disetujui oleh Lembaga walaupun belum dilakukan secara konsisten

\section{KESIMPULAN}

Berdasarkan hasil analisis dari penelitian yang dilakukan pada STIMIK Sepuluh Nopember Jayapura maka dapat ditarik beberapa kesimpulan.

1. Tingkat kematangan pada proses PO5 dan DS6 berada pada level 2 Repeatable but Intuitive dimana level ini proses yang bejalan dibuatkan prosedur untuk pekerjaan yang sama untuk dipakai oleh berbagai pihak. Belum ditemukan pelatihan formal atau sosialisasi aturan standar dan tanggung jawab diserahkan kepada masing -masing PIC. Kepercayaan yang tinggi 
terhadap pengetahuan individu/perorangan sehingga kemungkinan terjadi kesalahan sangat besar.

2. Belum dilakukan alokasi anggaran TI secara konsisten, Serta pencatatan dan pengawasan dilakukan secara informal.

3. Komunikasi antar departemen yang lemah, prosedur cenderung tanggung jawab diserahkan pada masing-masing individu sehingga kemungkinan kesalahan terjadi sangat besar.

4. Semua proses akuntansi belum didokumentasikan secara formal.

5. Untuk mencapai tingkat kematangan pada level (4 Managed and Measurable) yakni pada prosesnya Manajemen mengawasi dan mengukur kepatutan terhadap prosedur dan mengambil tindakan jika proses tidak dapat dikerjakan secara efektif. Proses sedang dalam peningkatan yang konstan dan dapat memberikan praktek yang baik. Otomatisasi dan perangkat yang digunakan dalam batasan tertentu. Maka setidaknya Lembaga wajib menjalankan isyarat yang tertuang dalam COBIT yang di terjemahkan kedalam bentuk lain yakni rekomendasi.

6. Terdapat Gap yang cukup jauh antara tingkat kematangan pada proses yang sedang dijalankan dan proses yang diharapkan yakni sebesar 2 untuk menuju pada tingkat 4 .

\section{SARAN}

Dari hasil penelitian ini peneliti memberikan beberapa saran kepada calon peneliti selanjutnya yang ingin mengembangkan ruang lingkup dari penelitian ini dan kepada STIMIK Sepuluh Nopember Jayapura:

1. Diharapkan bagi calon peneliti selanjutnya dapat memperluas ruang lingkup penelitian pada tujuan bisnis dan tujuan teknologi informasi yang lain sehingga didapatkan tata kelola yang baik disetiap proses yang dianjurkan oleh framework COBIT 4.1

2. Setiap proses pada Lembaga perlu diformalkan baik dalam bentuk administrasi maupun sistem akuntasi, dan dilakukan secara konsisten dan berkelanjutan,

3. Perlu dibuat pengawasan dan pelatiahan formal pada setiap tingkatan manajemen.

\section{DAFTAR PUSTAKA}

[1] Darmanto, Y., Suyanto . M., Sudarmawan, 2014, Analisis Tata Kelola Teknologi Informasi Pada Lembaga Kursus dan Pelatihan, Citec Journal, Vol 1. No. 2, Hal 102 - 115.

[2] Tim Penyusun, 2016, Rencana Strategis STIMIK Sepuluh Nopember Jayapura 2016-2021, Jayapura

[3] Marzuki, K., 2018, Audit Tata Kelola Teknologi Informasi Menggunakan Cobit 4.1 Domain Monitoring Evaluasi Pada Perguruan Tinggi Swasta, SENSITEK, Pontianak, 12 Juli.

[4] Information Technology Governance Institute, 2005, Cobit 4.1, Framework Control Objectives, Management Guidelines, Maturity Models, IT Governance Institute, Rolling Meadows, United States.

[5] Lesmono, I .D., Erica, D., 2018, Tata Kelola Teknologi Informasi Dengan Metode COBIT 4.1 (Studi Kasus : PT IMI), Jurnal Kaijian Ilmiah, Vol. 18 No. 1, Hal 75 - 84.

[6] Haerani, R., 2017, Mengukur Tingkat Kinerja Tata Kelola Teknologi Informasi di Perguruan Tinggi Menggunakan IT Balanced Scorecard, Jurnal Sistem Informasi, Vol 4, Hal 25 - 28.

[7] Hery, 2017, Balanced Scorecard for Business, Gramedia Widiasarana Indonesia, Jakarta.

[8] Fauzan R., Latifah, R., 2015, Audit Tata Kelola Teknologi Informasi Untuk Mengontrol Manajemen Kualitas Menggunakan Cobit 4.1 Studi Kasus: PT Nikkatsu Electric Works, JuTISI, Vol. 1 No. 3, Hal 235 - 244. 
Citec Journal, Vol. 5, No. 2, Februari 2018 - April 2018

ISSN: 2460-4259

[9] Faizal., M., 2013, Analisa Tingkat Kematangan Tata Kelola pada Sistem Informasi Akademik Perguruan Tinggi XYZ Berdasarkan Domain ME COBIT Versi 5.0., Laporan Penelitian Hibah Bersaing, Project Multitahun, Dikti, Jakarta.

[10] Information Technology Governance Institute, 2007, Cobit 4.1, Framework Control Objectives, Management Guidelines, Maturity Models, IT Governance Institute, Rolling Meadows, United States.

[11] Daryanto., Trihargo, G., Pratignyo, C. I., 2002, Audit Sistem Informasi II, Yayasan Pendidikan Internal Audit, Jakarta.

[12] Sumarsan, T., 2010, Sistem pengendalian Manajemen. PT Index, Jakarta

[13] Gunawan, B., 2000, Balanced Scorecard: Perspektif Baru dalam Menilai Kinerja Organisasi, Jurnal akuntansi \& Investasi, Vol. 1 No. 1, Hal. 41 - 51.

[14] Syarifudin, G, 2013, Perencanaan Strategis Sistem Infomasi Pengukuran Kinerja Dosen dengan Menggunakan IT-Balanced Scorecard, Jurnal Sisfotenika, Vol. 3, No. 1, Hal 61 70 .

[15] Ahmadi, R., 2016, Metodologi Penelitian Kualitatif, AR-RUZZ MEDIA, Yogyakarta

[16] Sarno, R., 2009, Audit Sistem dan Teknologi Informasi, UPT Penerbitan ITS(ITS PRESS), Surabaya

[17] Murhada., Giap, C. Y., 2011, Pengantar Teknologi Informasi, Mitra Wacana Media, Tangerang. 